\title{
Serum Levels of Beta-2 Microglobulin in Rheumatoid Arthritis Patients and its Relationship with Disease Activity: Can it be used as a Disease Activity Marker?
}

\section{Serum-Beta-2-Mikroglobulin-level bei Patienten mit rheumatoider Arthritis und ihre Beziehung zur Krankheitsaktivität: Kann es als Krankheitsaktivitätsmarker verwendet werden?}

Authors

Ayşe Bahar Keleşoğlu Dinçer ${ }^{1}$, Murat Torgutalp² (1), Müçteba Enes Yayla3 (D), Emine Gözde Aydemir Gülöksüz',

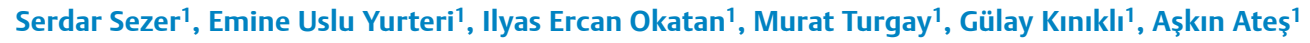

Affiliations

1 Rheumatology, Ankara University Faculty of Medicine, Ankara

2 Department of Internal Medicine, Division of Rheumatology, Ankara University Faculty of Medicine, Ankara

3 Department of Rheumatology, Ankara University Faculty of Medicine, Ankara

Key words

beta 2 microglobulin, rheumatoid arthritis, ankylosing spondylitis

\section{Schlüsselwörter}

Beta-2-Mikroglobulin, Rheumatoide Arthritis, Spondylitis ankylosans

published online 19.11.2020

Bibliography

Akt Rheumatol 2021; 46: 297-304

DOI 10.1055/a-1289-8809

ISSN 0341-051X

(C) 2020. Thieme. All rights reserved.

Georg Thieme Verlag KG, Rüdigerstraße 14,

70469 Stuttgart, Germany

Correspondence

Dr. Ayşe Bahar Keleşoğlu Dinçer

Rheumatology

Ankara University Faculty of Medicine

ibni Sina hastanesi

06340 Ankara

Turkey

Tel.: 03125082234 , Fax : 03125082234

bdincer@ankara.edu.tr

\section{ABSTRACT}

Background Beta- 2 microglobulin $(\beta 2 \mathrm{M})$ is mainly released from activated lymphocytes. Increased serum $\beta 2 M$ levels have been shown in autoimmune diseases. The aim of this study was to analyse the serum levels of $\beta 2 \mathrm{M}$ in rheumatoid arthritis (RA) patients and to evaluate its relationship with disease activity measures.

Material and Methods This cross-sectional study included 137 RA patients, 102 ankylosing spondylitis patients (AS) and 50 healthy controls (HC). To assess the disease activity of RA patients, the 28-joint Disease Activity Score-Erythrocyte Sedimentation Rate (DAS28-ESR), the 28-joint Disease Activity Score-C-Reactive Protein (DAS28-CRP), the Simplified Disease Activity Index (SDAI) and the Clinical Disease Activity Index (CDAI) were used. A p value of $<0.05$ was considered statistically significant.

Results Serum $\beta 2 \mathrm{M}$ levels were significantly higher in RA patients $(2.95 \pm 1.19 \mathrm{mg} / \mathrm{L})$ compared with HC $(2.21 \pm 0.54 \mathrm{mg} / \mathrm{L})$ and AS patients $(2.200 .58 \mathrm{mg} / \mathrm{L})(\mathrm{p}<0.001)$. There was a statistically significant correlation between $\beta 2 \mathrm{M}$ levels and DAS28$\operatorname{ESR}(r s=0.359, p<0.001)$, DAS28-CRP ( $r s=0.293, p=0.001)$, SDAI ( $r s=0.332, p<0.001)$ and CDAI $(r s=0.291, p=0.001)$. Serum $\beta 2 \mathrm{M}$ levels were higher in the RA group with DAS28ESR $\geq 3.2(3.30 \pm 1.42 \mathrm{mg} / \mathrm{L})$ than in the DAS28-ESR $<3.2$ group $(2.67 \pm 0.87 \mathrm{mg} / \mathrm{L})(\mathrm{p}=0.002)$.

Conclusion Our study revealed that serum $\beta 2 \mathrm{M}$ levels were higher in RA patients than in healthy controls, and, in contrast to other studies, we found positive correlations between $\beta 2 \mathrm{M}$ levels and RA disease activity measures.

\section{ZUSAMMENFASSUNG}

Hintergrund Beta-2-Mikroglobulin ( $\beta 2 \mathrm{M})$ wird hauptsächlich aus aktivierten Lymphozyten freigesetzt. Erhöhte Serumlevel von $\beta 2 \mathrm{M}$ wurden bei Autoimmunerkrankungen nachgewiesen. Ziel dieser Studie war es, die Serum $\beta 2 \mathrm{M}$-Level bei Patienten mit rheumatoider Arthritis (RA) zu analysieren und ihren Zusammenhang mit Messungen der Krankheitsaktivität zu bewerten.

Material-Methoden Diese Querschnittsstudie umfasste 137 RA, 102 Patienten mit Morbus Bechterew (MB) und 50 gesunde Kontrollen (GK). Zur Beurteilung der Krankheitsaktivität von RA-Patienten wurden 28 Gelenkaktivitäts-Score Blutsenkungsgeschwindigkeit (DAS28-BSG), 28 Gelenkaktivitäts-Score 
C-reaktives Protein (DAS28-CRP), vereinfachter Krankheitsaktivitätsindex (SDAI) und klinischer Krankheitsaktivitätsindex (CDAI) verwendet. Ein p-Wert von $<0,05$ wurde als statistisch signifikant angenommen.

Ergebnisse Die Serum $\beta 2 \mathrm{M}$ Konzentrationen waren bei RAPatienten $(2,95 \pm 1,19 \mathrm{mg} / \mathrm{L})$ signifikant höher als bei GK $(2,21 \pm 0,54 \mathrm{mg} / \mathrm{L})$ und Spondylitis ankylosans (AS)-Patienten $(2,20 \pm 0,58 \mathrm{mg} / \mathrm{L})(\mathrm{p}<0,001)$. Es bestand eine statistisch signifikante Korrelation zwischen den $\beta 2 \mathrm{M}$ Werten und DAS28-
BSG ( $r s=0,359, p<0,001)$, DAS28-CRP $(r s=0,293, p=0,001)$, SDAI ( $r s=0,332, p<0,001), \operatorname{CDAl}(r s=0,291, p=0,001)$. Die Serum $\beta 2 \mathrm{M}$-Levels waren in der RA-Gruppe mit DAS28$E S R \geq 3.2(3,30 \pm 1,42 \mathrm{mg} / \mathrm{L})$ höher als in der DAS28ESR $<3,2$-Gruppe $(2,67 \pm 0,87 \mathrm{mg} / \mathrm{L})(\mathrm{p}=0,002)$.

Diskussion Unsere Studie zeigte, dass die Serum $\beta 2 \mathrm{M}$-Levels bei der RA höher als bei gesunden Kontrollen waren. Außerdem fanden wir positive Korrelationen zwischen den $\beta 2 \mathrm{M}$-Levels und den Aktivitätswerten der RA im Gegensatz zu anderen Studien.

\section{Introduction}

Rheumatoid arthritis, is a systemic chronic autoimmune disease which is characterized by inflammatory synovitis in peripheral joints [1]. In the pathogenesis of RA, the activation of CD4 + T lymphocytes plays a key role [2]. As a result, organized proinflammatory cytokine secretion managed by $T$ and $B$ lymphocytes has a regulatory role in the pathophysiology of RA [1]. The synovial membranes of RA patients are infiltrated with activated T lymphocytes, B lymphocytes, plasma cells, macrophages and mast cells [2] .

Beta-2 microglobulin is a low molecular weight (11800 Dalton) protein which is synthesized in all nucleated cells including lymphocytes and macrophages and constitutes the light-chain subunit of the class 1 human leucocyte antigen (HLA) $[3,4]$. The duty of $\beta 2 M$ is to stabilize the major histocompatibility complex-1 (MHC 1) on the cell membrane, to protect the native structure of its heavy chain and also it provides high affinity antigenic peptide bindings [5]. It is found in small amounts in biological fluids such as serum, urine, colostrum, saliva, amniotic fluid and synovial fluid [6, 7]. During the continuous turnover of HLA molecules, $\beta 2 \mathrm{M}$ gets into the blood by sheding from the cell membrane and forms the serum free $\beta 2 \mathrm{M}$ [8]. Especially lymphocyte and monocyte surfaces are rich in $\beta 2 \mathrm{M}$, and the main sources of serum free $\beta 2 \mathrm{M}$ are activated $\mathrm{T}$ and $B$ lymphocytes [7, 9]. As it is a protein with low molecular weight, it is easily filtered from the glomerular basal membrane in the kidneys, but $99 \%$ of the filtered $\beta 2 \mathrm{M}$ is reabsorbed in the proximal tubules by endocytosis $[7,10]$. Serum $\beta 2 \mathrm{M}$ levels are independent of sex and body mass, but they are mildly higher in the elderly due to the decreased glomerular filtration rate (GFR) [10]. As the main sources of serum $\beta 2 \mathrm{M}$ are lymphocytes, the serum levels increase in lymphoproliferative and autoimmune diseases where the $T$ and $B$ lymphocyte activity increases [9]. Increased serum $\beta 2 M$ levels have been shown in autoimmune diseases [4, 11-13].

The aim of this study is to investigate the serum $\beta 2 \mathrm{M}$ levels in rheumatoid arthritis patients and its relationship with disease activity.

\section{Material and Methods}

\section{Patients and Study Design}

One hundred and thirty-seven RA, 102 Ankylosing Spondylitis (AS) and 50 healthy controls (HC) followed in the Rheumatology Department of Ankara University Faculty of Medicine between April 2019 and December 2019 were recruited for this cross-sectional study. RA patients included in the study were diagnosed based on the 2010 American College of Rheumatology- European League against Rheumatism classification criteria and AS patients according to Modified New York Criteria $[14,15]$. Patients with lymphoproliferative diseases, cancer, autoimmune or autoinflammatory diseases other than RA and AS, acute or chronic infections and patients with decreased glomerular filtration rate, pregnant and breastfeeding patients were excluded from the study. The data collection at baseline included demographic characteristics, symptom duration, the tender and swollen joint count on 28 joints (TJC28, SJC28), the patient's (Pt-VAS) and physician's assessment of disease activity on a $0-10 \mathrm{~cm}$ Visual Analogue Scales (VAS), comorbidities and treatment features.

\section{Assessment of Disease Activity}

Disease activity assessment for RA patient were performed by Disease Activity Score for 28 joints with Erythrocyte Sedimentation Rate, Disease Activity Score for 28 joints with C-reactive protein (CRP), Simplified Disease Activity Score and Clinical Disease Activity Score [16-18]. As DAS28-ESR is a widely accepted index for RA studies, we classified RA patients into 2 groups as follows: remission and low disease activity group with DAS28-ESR <3.2 and moderate to high disease activity group with DAS28-ESR $\geq 3.2$

In order to evaluate disease activity in Ankylosing Spondylitis patients Bath Ankylosing Spondylitis Disease Activity Index (BASDAI), Bath Ankylosing Spondylitis Functional Index (BASFI), Ankylosing Spondylitis Disease Activity Score-CRP (ASDAS-CRP) and Ankylosing Spondylitis Disease Activity Score-ESR (ASDAS-ESR) were used [19-21].

\section{Laboratory Analysis}

Routine laboratory tests such as complete blood cell count, ESR, CRP, glomerular filtration rate were investigated by using standard laboratory methods. Serum $\beta 2 \mathrm{M}$ levels were evaluated by turbidimethric method.

\section{Ethical considerations}

The study was approved by Ankara University Faculty of Medicine Ethics Board.

\section{Statistical Analysis}

The data was analyzed by using IBM SPSS version 21 (SPSS, Chicago,III). Categorical data was summarized by frequencies and 
- Table 1 Demographic and clinical characteristics of RA, AS patients and healthy controls.

\begin{tabular}{|c|c|c|c|c|}
\hline & RA & AS & Healthy Control & $\mathbf{p}$ \\
\hline Sex, male, n (\%) & $28(20.4)$ & $65(63.7)$ & $15(30.0)$ & $<0.001$ \\
\hline Age, years, mean $( \pm S D)$ & $55.1 \pm 11.2$ & $43.4 \pm 11.9$ & $49.8 \pm 12.2$ & $<0.001$ \\
\hline Diagnosis duration, median (min-max) & $9(0.1-444)$ & $84(1-240)$ & - & - \\
\hline RF positivity, $\mathrm{n}(\%)$ & $84(61.31)$ & & & \\
\hline ACPA positivity, $n$ (\%) & $76(55.47)$ & & & \\
\hline TJC, median (min-max) & $1(0-20)$ & & & \\
\hline SJC, median (min-max) & $0(0-10)$ & & & \\
\hline \multicolumn{5}{|l|}{ Comorbidities, n (\%) } \\
\hline Hypertension & $36(26.28)$ & & & \\
\hline Diabetes mellitus & $17(12.41)$ & & & \\
\hline Hyperlipidemia & $2(1.46)$ & & & \\
\hline Hypothyroidism & $11(8.03)$ & & & \\
\hline Coronary Artery Disease & $3(2.19)$ & & & \\
\hline Asthma & $5(3.65)$ & & & \\
\hline Atrial fibrillation & $1(0.72)$ & & & \\
\hline Benign prostate hyperplasia & $3(2.19)$ & & & \\
\hline \multicolumn{5}{|l|}{ Treatment, $\mathbf{n}(\%)$} \\
\hline Corticosteroid & $55(40.14)$ & & & \\
\hline Hydroxychloroquine & $66(48.18)$ & & & \\
\hline Methotrexate & $65(47.44)$ & & & \\
\hline Leflunomide & $38(27.74)$ & & & \\
\hline Sulfasalazine & $27(19.71)$ & & & \\
\hline TNF-inhibitors & $11(8.03)$ & & & \\
\hline Tocilizumab & $10(7.29)$ & & & \\
\hline Rituximab & $22(16.06)$ & & & \\
\hline Tofacitinib & $6(4.38)$ & & & \\
\hline Abatacept & $5(3.65)$ & & & \\
\hline \multicolumn{5}{|l|}{ Disease Activity } \\
\hline DAS28-ESR, mean ( \pm SD) & $3.32( \pm 1.23)$ & & & \\
\hline DAS28-CRP, mean ( \pm SD) & $3.62( \pm 1.42)$ & & & \\
\hline SDAI, mean $( \pm$ SD $)$ & $22.92( \pm 25.69)$ & & & \\
\hline CDAI, mean $( \pm S D)$ & $9.85( \pm 7.40)$ & & & \\
\hline BASDAI & & $2.60 \pm 1.92$ & & \\
\hline BASFI & & $2.09 \pm 1.56$ & & \\
\hline ASDAS-CRP & & $2.25 \pm 2.58$ & & \\
\hline ASDAS-ESR & & $1.72 \pm 0.93$ & & \\
\hline PtVAS $(0-10 \mathrm{~mm})$ & $3.26( \pm 2.08)$ & $3.44 \pm 2.74$ & & \\
\hline \multicolumn{5}{|l|}{ Laboratory features } \\
\hline ESR, mm/h, median (min-max) & $21(3-95)$ & $8(1-87)$ & $11(2-34)$ & $<0.001$ \\
\hline CRP, mg/L, median (min-max) & $5.9(0.1-217.0)$ & $4.2(0.0-144.8)$ & $2.5(0.1-25.2)$ & $<0.001$ \\
\hline White blood cell, x109/L, median (min-max) & $7620(2270-22930)$ & $8515(3980-14740)$ & $6865(4410-11470)$ & 0.003 \\
\hline Hemoglobin, g/dL, median (min-max) & $12.6 \pm 1.5$ & $14.4 \pm 1.6$ & $14.1 \pm 1.7$ & $<0.001$ \\
\hline Platelet, x1099/L, median (min-max) & $282(120-607)$ & $291(158-754)$ & $277(168-483)$ & 0.540 \\
\hline Beta-2 microglobulin, mg/L, median (min-max) & $2.95 \pm 1.19$ & $2.20 \pm 0.58$ & $2.21 \pm 0.54$ & $<0.001$ \\
\hline
\end{tabular}


- Table 2 Clinical and laboratory features of RA patients grouped according to disease activity based on DAS28-ESR.

\begin{tabular}{|c|c|c|c|}
\hline & DAS28-ESR $<3.2(n=75)$ & DAS28-ESR $\geq 3.2(n=62)$ & $\mathbf{p}$ \\
\hline Age, years, mean $( \pm S D)$ & $54.0 \pm 11.5$ & $56.4 \pm 10.8$ & 0.205 \\
\hline Sex, male, n (\%) & $19(25.3)$ & $9(14.5)$ & 0.118 \\
\hline Disease Duration, median (min-max) & $9.5(0.1-444.0)$ & $8.5(0.5-156.0)$ & 0.608 \\
\hline RF positivity, $\mathrm{n}(\%)$ & $44(58.7)$ & $42(67.7)$ & 0.274 \\
\hline ACPA positivity, $n(\%)$ & $48(64.0)$ & $42(67.7)$ & 0.646 \\
\hline ESR, mm/h, median, (min-max) & $14(3-50)$ & $27(8-95)$ & $<0.001$ \\
\hline CRP, mg/L, median, (min-max) & $3.9(0.1-217.0)$ & $10.5(0.7-158.9)$ & $<0.001$ \\
\hline White blood cell, $\times 10^{9} / \mathrm{L}$, median (min-max) & $7030(3100-22930)$ & $8075(2270-20720)$ & 0.215 \\
\hline Hemoglobin, g/dL, median (min-max) & $13.0 \pm 1.4$ & $12.1 \pm 1.4$ & $<0.001$ \\
\hline Platelet, $\times 10^{9} / \mathrm{L}$, median (min-max) & $276(134-530)$ & $296(120-607)$ & 0.057 \\
\hline Beta-2 microglobulin, mg/L, mean (SD) & $2.67 \pm 0.87$ & $3.30 \pm 1.42$ & 0.002 \\
\hline
\end{tabular}

ACPA: Anti-citrullinated peptide antibodies, CRP: C-reactive protein, ESR: Erythrocyte sedimentation rate, RF: Rheumatoid factor, SD: Standard deviation.

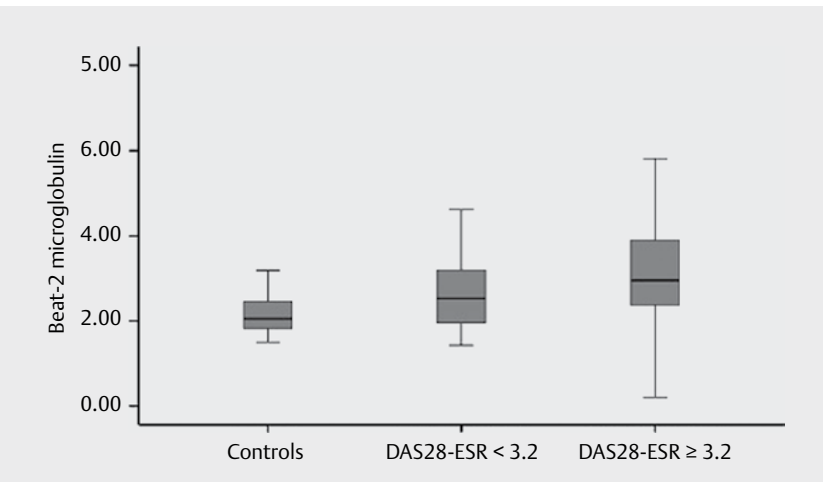

Fig. 1 Beta-2 microglobulin levels of RA patients grouped according to the disease activity based on DAS28-ESR and healthy controls.

percentages and quantitative data was given as means \pm standard deviation (SD) or medians and minimum-maximum based on their distribution. Intergroup differences were evaluated by Mann-Whitney $U$ test. The relationship between parameters were assessed using Spearman rank correlation test. Power analyses were performed using $G$ " Power version 3.0.10 power and sample size calculation. A p value $<0.05$ was considered statistically significant.

\section{Results}

The demographic and clinical data of the RA and AS patients and the healthy controls were summarized in $>$ Table 1 . There was a significant age difference among the 3 groups $(p<0.001)$. There was no significant sex difference between RA and HC $(p=0.169)$. Serum $\beta 2 \mathrm{M}$ levels were significantly higher in RA patients $(2.95 \pm 1.19 \mathrm{mg} / \mathrm{L})$ when compared to both AS $(2.20 \pm 0.58 \mathrm{mg} / \mathrm{L})$ and $H C(2.21 \pm 0.54)$ $(p<0.001$ and $p<0.001$, respectively). However, there was no sta- tistically significant difference in serum $\beta 2 \mathrm{M}$ levels between AS and healthy controls $(p=1.000)$.

The RA patients were classified into 2 groups according to their disease activity based on DAS28-ESR. The serum $\beta 2 \mathrm{M}$ levels in the moderate to high disease activity group (DAS-28 $\geq 3.2$ ) were significantly higher than remission and low disease activity group with DAS28-ESR $<3.2(p=0.002)(\triangleright$ Table 2$)(\triangleright$ Fig. 1$)$. Likewise, the ESR and CRP levels in the DAS28-ESR $\geq 3.2$ group were significantly higher than the DAS28-ESR $<3.2$ group $(p<0.001$ and $p<0.01$, respectively). The hemoglobin level, on the other hand, was significantly lower in the DAS28-ESR $\geq 3.2$ group $(p<0.001)$ ( $\triangleright$ Table 2 ).

There were positive correlations between serum $\beta 2 \mathrm{M}$ levels and $\operatorname{DAS} 28-\operatorname{ESR}\left(r_{s}, 0.359 ; p<0.001\right)$, DAS28-CRP $\left(r_{s}, 0.293 ; p=0.001\right)$, $\operatorname{SDAl}\left(r_{s}, 0.332 ; p<0.001\right)$ and $\operatorname{CDAl}\left(r_{s}, 0.291 ; p=0.001\right)$ ( $\vee$ Fig. 2$)$. Even though there was no correlation between TJC28 and serum $\beta 2 \mathrm{M}\left(r_{s}, 3.131 ; p=0.334\right)$, there was statistically significant positive correlations between serum $\beta 2 \mathrm{M}$ and $S \mathrm{SJ} 28\left(r_{s}, 0.348 ; p=0.009\right)$, $\operatorname{ESR}\left(r_{s}, 0.430 ; p<0.001\right)$ and $\operatorname{CRP}\left(r_{s}, 0.246 ; p=0.004\right)$ ( $\triangleright$ Table 3)

No correlations were observed between serum $\beta 2 \mathrm{M}$ levels and disease activity indices of AS such as ASDAS-CRP, ASDAS-ESR, BASDAI and BASFI. ( $\vee$ Table 4) However, there were statistically significant positive correlations between serum $\beta 2 \mathrm{MG}$ levels and ESR $\left(r_{s}, 0.277 ; p=0.006\right)$ and $\operatorname{CRP}\left(r_{s}, 0.297 ; p=0.003\right)$.

Elevated $\beta 2 \mathrm{M}$ levels were found in $76.3 \%$ of RA patients with $\geq 1$ swollen joint count whereas elevated $\beta 2 \mathrm{M}$ levels were found in $51.5 \%$ of RA patients without any swollen joint $(p=0.008)$. When the elevated CRP levels were compared, $68.4 \%$ of RA patients with $\geq 1$ swollen joint had elevated CRP levels and $49 \%$ of RA patients without any swollen joint had elevated CRP levels $(p=0.041)$ ( $\triangleright$ Table 5). 

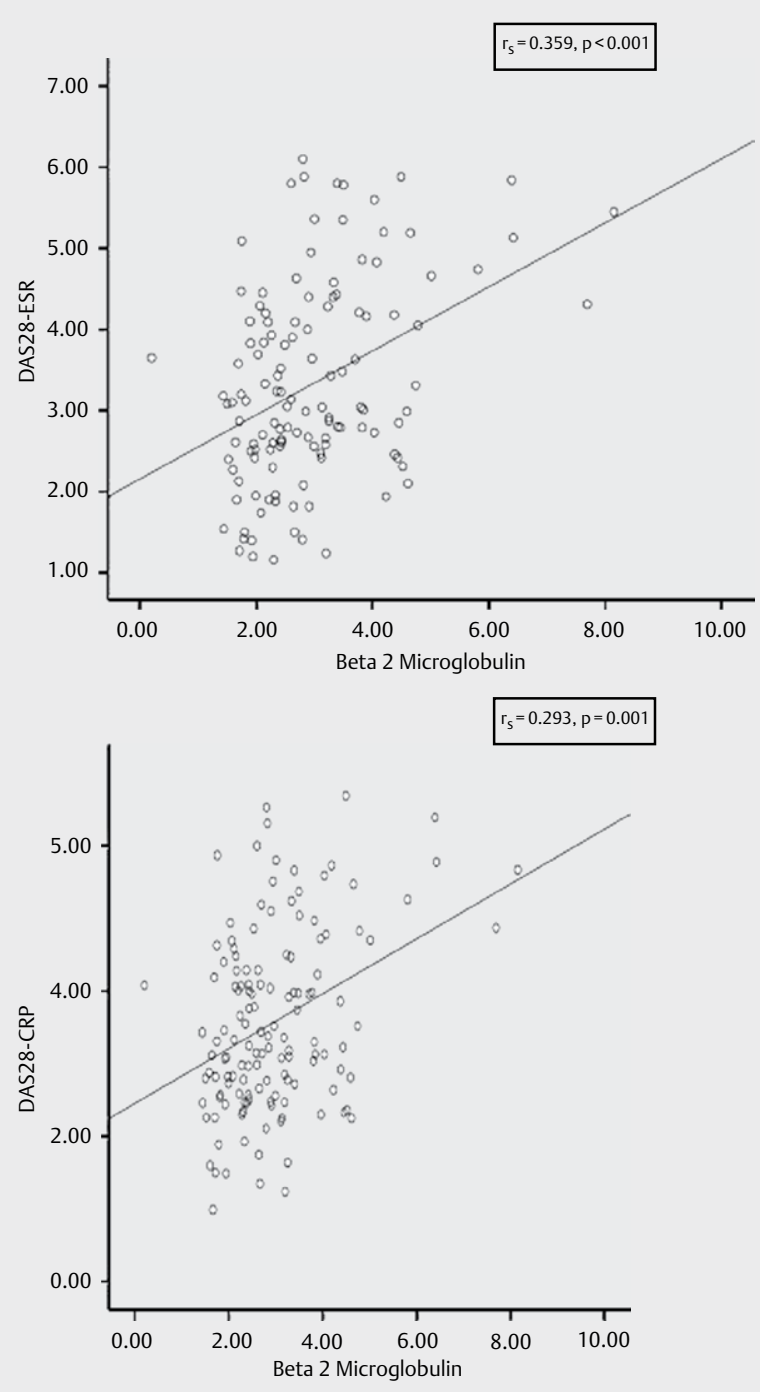

- Fig. 2 Correlation of Beta-2 microglobulin with DAS28-ESR and DAS28-CRP in RA patients.

\section{Discussion}

Since it was isolated from the urine of patients with renal tubular dysfunction in 1968 by Berggard and Bearn, $\beta 2 \mathrm{M}$ has been a subject to several studies [22]. As most of the free $\beta 2 \mathrm{M}$ in the circulation is excreted by glomerular filtration, it may be used for measuring the GFR [23]. While the main source of serum free $\beta 2 \mathrm{M}$ is lymphocytes; an increase in the serum levels may be related either to renal dysfunction or to lymphocyte activation in lymphoproliferative or autoimmune diseases in patients with normal renal function $[4,24]$. In a study with 100 SLE patients, the serum $\beta 2 \mathrm{M}$ levels were found significantly higher in SLE patients when compared to the healthy control group ( $p<0.001)$, and it was shown that there is a significant correlation between serum $\beta 2 \mathrm{M}$ levels and SLE activity indices such as anti-dsDNA, complement and hemoglobin levels and the Systemic Lupus Erythematosus Disease Activity index (SLEDAI) [9]. In a study conducted by Aghdashi et al. with 50 SLE pa- tients, the serum $\beta 2 \mathrm{M}$ levels were found to be significantly higher than healthy controls and were related to SLE disease activity ( $p<0.001$ and $p<0.001$, respectively) [24]. In a similar study by Zychowska et al. with 69 SLE patients, it was shown that serum $\beta 2 \mathrm{M}$ levels correlated with SLEDAI, complement 4 levels and anti-dsDNA titers [25]. In a multicentric study carried out by Gottenberg et al. with primary Sjögren's syndrome patients at 15 centers, it was demonstrated that increased $\beta 2 \mathrm{M}$ levels were associated with increased EULAR Sjögren's Syndrome Disease Activity Index $(p<0.001)$ [26]. A study conducted with 192 Sjögren's syndrome patients, it was shown that the unstimulated whole salivary $\beta 2 \mathrm{M}$ levels in both primary and secondary Sjögren's syndrome patients were significantly higher than both the healthy control group and the non-Sjögren sicca symptom group [27].

On the one hand, studies demonstrating increased serum $\beta 2 \mathrm{M}$ levels in autoimmune diseases and positively correlated with disease activity indices have been popular in recent years. On the other hand, there are a few studies in the literature evaluating the relationship between RA and serum $\beta 2 \mathrm{M}$ levels which were conducted almost 3 decades ago. For this reason, in this study, we aimed to analyze the serum $\beta 2 \mathrm{M}$ levels in RA patients and its correlation with disease activity indices. Our study included a total of 137 RA patients. Even though, there was a significant age difference between 3 study groups; as serum $\beta 2 \mathrm{M}$ levels do not vary according to age or sex as long as GFR is within normal range, the differences among the groups were not assumed to be significant. In similarity to the few previous studies with RA patients, we found significantly higher serum $\beta 2 \mathrm{M}$ levels in RA patients in comparison to the healthy control group. As far as we know, the first study on RA patients was conducted in 1975 and reported that $\beta 2 \mathrm{M}$ levels in the synovial fluid specimens collected from ten active RA patients, 11 non-RA inflammatory arthritis and 8 degenerative arthritis patients were significantly higher in RA patients when compared to the other 2 groups ( $p<0.01$ and $p<0.001$, respectively) [28]. In 1978, Manicourt et al. examined the $\beta 2 \mathrm{M}$ levels in the plasma and 24-hour urine of 21 RA patients and showed that the plasma $\beta 2 \mathrm{M}$ levels were at the upper limit of normal in more than $50 \%$, and the urine $\beta 2 \mathrm{M}$ levels were at the upper limit of normal in the $30 \%$ of the patients [29]. In the study carried out in 1980 by Sjöblom et al. with 135 RA patients, the plasma $\beta 2 \mathrm{M}$ concentration was found to be high in $33 \%$ of the patients [30]. A study in 1981 with 20 healthy control and 44 RA patients found significantly increased serum $\beta 2 \mathrm{M}$ levels in RA patients [3]. In 1989, in a study including 57 active RA patients, the mean $\beta 2 \mathrm{M}$ levels in both serum and synovial fluids of RA patients were found to be significantly high, but the synovial fluid $\beta 2 \mathrm{M}$ levels were found to be higher than the serum levels in $76 \%$ of the patients [31]. While $\beta 2 \mathrm{M}$ is expressed at a certain level in most cells, its expression is stimulated especially in the presence of interferon- $\alpha$ (IFN- $\alpha$ ) [32]. Increased $\beta 2 \mathrm{M}$ induces interleukin 6 (IL-6), IL-8 and IL-10 expressions and coordinates the relationship between cytokines and receptors $[6,33,34]$. It is believed that IFN- $\alpha$ may have a role in the pathogenesis of RA. Increased IFN- $\alpha$ levels were shown in the synovial tissues and peripheral circulation of RA patients [35-36].

In this study, in difference to previous studies, DAS28-ESR, DAS28-CRP, SDAI and CDAI were used to assess RA disease activity. We found a significant positive correlation between the serum 
- Table 3 Correlation of RA disease activity indices with serum Beta-2 microglobulin levels.

\begin{tabular}{|c|c|c|}
\hline & & Beta-2 microglobulin \\
\hline \multirow[t]{2}{*}{ DAS28-ESR } & $r_{s}$ & 0.359 \\
\hline & p & $<0.001$ \\
\hline \multirow[t]{2}{*}{ DAS28-CRP } & $r_{s}$ & 0.293 \\
\hline & P & 0.001 \\
\hline \multirow[t]{2}{*}{ TJC28 } & $r_{s}$ & 0.131 \\
\hline & P & 0.334 \\
\hline \multirow[t]{2}{*}{ SJC28 } & $r_{s}$ & 0.348 \\
\hline & P & 0.009 \\
\hline \multirow[t]{2}{*}{ ESR } & $r_{s}$ & 0.430 \\
\hline & $\mathrm{P}$ & $<0.001$ \\
\hline \multirow[t]{2}{*}{ CRP } & $r_{s}$ & 0.246 \\
\hline & P & 0.004 \\
\hline \multirow[t]{2}{*}{ SDAI } & $r_{s}$ & 0.332 \\
\hline & $\mathrm{p}$ & $<0.001$ \\
\hline \multirow[t]{2}{*}{ CDAI } & $r_{s}$ & 0.291 \\
\hline & $\mathrm{P}$ & 0.001 \\
\hline
\end{tabular}

- Table 4 Correlation of AS disease activity indices with serum Beta-2 microglobulin levels.

\begin{tabular}{|c|c|c|}
\hline & & Beta-2 microglobulin \\
\hline \multirow[t]{2}{*}{ ASDAS-CRP } & $r_{s}$ & 0.050 \\
\hline & $\mathrm{p}$ & 0.622 \\
\hline \multirow[t]{2}{*}{ ASDAS-ESR } & $r_{s}$ & 0.070 \\
\hline & $\mathrm{p}$ & 0.492 \\
\hline \multirow[t]{2}{*}{ BASDAI } & $r_{s}$ & -0.013 \\
\hline & $\mathrm{p}$ & 0.895 \\
\hline \multirow[t]{2}{*}{ BASFI } & $r_{s}$ & -0.081 \\
\hline & $\mathrm{p}$ & 0.491 \\
\hline \multirow[t]{2}{*}{ CRP } & $r_{s}$ & 0.297 \\
\hline & $\mathrm{p}$ & 0.003 \\
\hline \multirow[t]{2}{*}{ ESR } & $r_{s}$ & 0.277 \\
\hline & $\mathrm{p}$ & 0.006 \\
\hline
\end{tabular}

$\beta 2 \mathrm{M}$ levels and these 4 indices. In the subgroup analysis, the RA patients were divided into 2 groups based on their disease activities according to DAS28-ESR. The serum $\beta 2 \mathrm{M}$ levels in the group with moderate and high disease activity with DAS28-ESR $\geq 3.2(n=62)$ were significantly higher than the group with remission and low disease activity group with DAS28-ESR <3.2 $(n=75)$. The serum ESR and CRP levels were also found to be significantly higher in the DAS28-ESR $\geq 3.2$ group. This result shows that serum $\beta 2 \mathrm{M}$ levels are related to disease activity. In contrast to previous studies, in our study we found a significant positive correlation between the serum $\beta 2 \mathrm{M}$ levels and ESR and CRP levels. Manicourt et al found no correlation between $\beta 2 \mathrm{M}$ and ESR [29]. Sjöblom et al found a weak relationship between $\beta 2 \mathrm{M}$ levels and other markers of joint inflammation [30]. In the study of Latt et al, no correlation was found between serum and urine $\beta 2 \mathrm{M}$ levels and ESR and lymphocyte counts [3]. On the other hand, similar to our study, in more recent studies conducted with autoimmune diseases other than RA, positive correlations between serum $\beta 2 \mathrm{M}$ levels and disease activity indices were found $[9,26]$. In a study by Aygündüz et al. with 43 Behçet syndrome patients, it was also shown that the serum $\beta 2 \mathrm{M}$ levels of the active patients were higher than those of the inactive patients and the healthy control group [4]. This difference could be explained by the largest number of RA patients included in our study and nowadays, laboratory measurements are more sensitive than approximately 30 years ago. Furthermore, in our study, we used RA disease activity indices that are frequently used in recent years and are more sensitive to assess disease activity, thus, we believe that our results are more reliable in reflecting disease activity in comparison to previous studies. In this study, we also found a significant relationship between the $\beta 2 \mathrm{M}$ levels and SJC, but we could not find the same relationship with TJC. This may be due to TJC being a more subjective finding depending on the patient's perception of pain, but SJC is more reliable in showing synovial inflammation.

In our study, we also compared serum $\beta 2 \mathrm{M}$ levels of the RA patients with 102 AS patients. Accordingly, the $\beta 2 \mathrm{M}$ levels of RA patients were found to be significantly higher than in AS patients. There was no significant difference between serum $\beta 2 \mathrm{M}$ levels of AS patients and healthy controls. In this study, the disease activity of AS patients were also assessed by BASDAI, BASFI, ASDAS-CRP and ASDAS-ESR, and the correlations between these scores and serum $\beta 2 M$ levels were examined. Consequently, no significant correlation was found between the serum $\beta 2 \mathrm{M}$ levels and BASDAI, BASFI, ASDAS-CRP and ASDAS-ESR. Nevertheless, as found in RA patients, there was a statistically significant correlation between $\beta 2 \mathrm{M}$ and ESR and CRP in AS patients. The results we found in AS pa-

- Table 5 Comparison of RA patients with elevated Beta-2 microglobulin and C-reactive protein with and without swollen joint counts

\begin{tabular}{|l|l|l|l|}
\hline & Swollen joint count $<\mathbf{1}(\mathbf{n = 9 9 )}$ & Swollen joint count $\geq \mathbf{1}(\mathbf{n = 3 8 )}$ & $\mathbf{P}$ value \\
\hline Elevated Beta-2 microglobulin, $\mathrm{n}(\%)$ & $51(51.5)$ & $29(76.3)$ & $\mathbf{0 . 0 0 8}$ \\
\hline Elevated C-reactive protein, $\mathrm{n}(\%)$ & $48(49)$ & $26(68.4)$ & $\mathbf{0 . 0 4 1}$ \\
\hline
\end{tabular}


tients were similar to previous studies in the literature. In a study by Wendling et al. with 28 AS patients, the serum $\beta 2 \mathrm{M}$ levels of the patients were found to be within normal limits, and no relationship was found between $\beta 2 \mathrm{M}$ levels and other inflammation markers [37]. In a study by Kepekçi et al. with 20 AS patients, the serum $\beta 2 \mathrm{M}$ levels were also found to be not significantly different than the control group, and its relationship with serum ESR, CRP and fibrinogen levels could not be demonstrated [38]. Beersma et al. found the serum $\beta 2 \mathrm{M}$ levels in HLA-B27 (+) acute anterior uveitis patients in normal limits and reported that the presence of concomitant AS did not change the result [39].

Our study had some limitations. First of all, this was a cross-sectional study. Prospective studies analyzing the changes in the serum $\beta 2 M$ levels of RA patients after treatment will be useful to clarify the relationship between serum $\beta 2 \mathrm{M}$ levels and RA.

To sum up, in this study it was found that serum $\beta 2 \mathrm{M}$ levels increase in RA patients and are correlated with disease activity. As measuring $\beta 2 \mathrm{M}$ is easy, fast and reliable, in patients without underlying renal or lymphoproliferative diseases, serum $\beta 2 \mathrm{M}$ can be used as a disease activity marker in RA patients.

\section{Conflict of Interest}

The authors declare no conflict of interest.

\section{References}

[1] Mateen S, Zafar A, Moin S et al. Understanding the role of cytokines in the pathogenesis of rheumatoid arthritis. Sinoviyal membran Clinica Chimica Acta 2016; 455: 161-171

[2] Brzustewicz E, Bryl E. The role of cytokines in the pathogenesis of rheumatoid arthritis- practical nd potential application of cytokines as biomarker and target of personalized therapy. Cytokine 2015; 76: 527-536

[3] Latt D, Weiss B], Jayson MIV. B2-microglobulin levels in serum and urine of rheumatoid arthritis patients on gold therapy. Ann Rheum Dis 1981; 40: 157-160

[4] Aygündüz M, Bavbek NÖztürk et al. Serum beta 2-microglobulin reflects disease activity in Behçet's disease. Rheumatol Int 2002; 22: $5-8$

[5] Ribaudo RK, Margulies DH. Independent and synergistic effects of disulfide bond formation, beta-2 microglobulin and peptides on class 1 MHC folding and assembly in an in vitro translation system. ] Immunol 1192: 149-2935-2944

[6] Li L, Dong M, Wang X-G. The implication and significance of beta 2 microglobulin: A conservative multifunctional regulator. Chinese Medical Journal 2016; 129: 448-455

[7] Bethea M, Forman DT. Beta-2 Microglobulin- An immunogenetic marker of inflammatory and malignant origin. Annals of Clinical and Laboratory Science 1982; 12: 447-452

[8] Leffers HCB, Hermansen ML, Sandholt B et al. Plasma levels of $\beta 2$-microglobulin are associated with atherosclerosis in patients with systemic lupus erythematosus: a cross-sectional cohort study. Lupus. 2018; 27: 1517-1523

[9] Kim HA, Jeon JY, Yoon JM et al. Beta2-microglobulin can be a disease activity marker in systemic lupus erythematosus. American Journal of Medical Sciences 2010; 339: 337-340
[10] Wibell LB. $\beta 2$-microglobulin in patients and normal subjects. Acta Clinica Belgica 1976; 31 (suppl8): 14-26

[11] Evrin PE, Strom T. Beta 2-microglobulin and its binding activity in serum from patients with SLE. Ann Rheum Dis 1984; 43: 267-274

[12] Strom T, Evrin PE, Karlsson A. Serum beta 2-microlgobulin in Sjögren's syndrome. Scand J Rheumatol 1978; 7: 97-100

[13] Zissis M, Afraoudakis A, Galanopoulos G et al. B2 microglobulin: Is it a reliable marker of activity in inflammatory bowel disease? The American Journal of Gastroenterology 2001; 7: 247-68.

[14] Aletaha D, Neogi T, Silman AJ et al. 2010 Rheumatoid arthritis classification criteria: an American College of Rheumatology/European League Against Rheumatism collaborative initiative. Arthritis Rheum 2010; 62: 2569-2581

[15] Van der Linden S, Vanlkenburg HA, Cats A. Evaluation of Diagnostic criteria for Ankylosing Spondylitis. A proposal for modification of the New York Criteria. Arthritis Rheum 1985; 27: 361-368

[16] van Gestel AM, Prevoo ML, van't Hof MA et al. Development and validation of the European League Against Rheumatism response criteria for rheumatoid arthritis. Comparison with the preliminary American College of Rheumatology and the World Health Organization/International League Against Rheumatism Criteria. Arthritis Rheum 1996; 39: 34-40

[17] Aletaha D, Nell VP, Stamm T et al. Acute phase reactants add little to composite disease activity indices for rheumatoid arthritis: validation of a clinical activity score. Arthritis Res Ther 2005; 7: R796-R806

[18] Smolen JS, Breedveld FC, Schiff MH et al. A simplified disease activity index for rheumatoid arthritis for use in clinical practice. Rheumatology (Oxford) 2003; 42: 244-257

[19] Garret S, Jenkinson T, Kennedy LG et al. A new approach to defining disease status in ankylosing spondylitis. The Bath Ankylosing spondylitis disease activity index. J Rheumatol 1994; 21: 2286-2291

[20] Calin A, Garret S, Whitelock H et al. A new approach to defining functional ability in ankylosing spondylitis: the development of the Bath Ankylosing Spondylitis Functional Index. J Rheumatol 1994; 21: 2281-2285

[21] Lukas C, Landewé R, Sieper J et al. Development of an ASAS-endorsed disease activity score (ASDAS) in patients with ankylosing spondylitis. Ann Rheum Dis 2009; 68: 18-24

[22] Berggard I, Bearn AG. Isolation and properties of a low molecular weight $\beta 2$-globulin occuring in human biological fluids. J Biol Chem 1968; 243: 4095-4103

[23] You L, Xie R, Haijuan $\mathrm{H}$ et al. High levels of serum $\beta$-2microglobulin predict severity of coronary artery disease. BMC Cardiovascular Disorders 2017; 17: 71

[24] Aghdashi M, Salami S, Nezhadisalami A. Evaluation of the serum $\beta 2$ microglobulin level in patients with systemic lupus erthematosus and its correlation with disease activity. BioMedicine 2019; 9: 6-11

[25] Zychowska I, Suszek D, Dryglewska M et al. B2-microglobulin as a marker of systemic lupus erythematosus activity. Adv Clin Exp Med 2018; 27: 379-382

[26] Gottenberg JE, Seror R, Miceli-Richard C et al. Serum levels of beta-2 microglobulin and free light chains of immunoglobulins are associated with systemic disease activity in primary Sjögren's syndrome. Data at enrollment in the prospective ASSESS Cohort. PLoS ONE 2013; 8: e59868. DOI: 10.1371/journal.pone.0059868

[27] Riega-Torres ], Delgado- Garcia G, Salas-Alanis JC et al. Beta-2 microglobulin in whole unstimulated saliva can effectivrly distinguish between sjögren's syndrome and non-autoimmune Sicca symptoms. Arch Rheumatol 2017; 32: 284-289

[28] Talal N, Grey HM, Zivaifler N et al. Elevated salivary and sinovial fluid B2-microglobulin in Sjögren's syndrom and rheumatoid arthritis. Scince 1975; 187: 1196-1198 
[29] Manicort D, Brauman H, Orloff S. Plasma and urinary levels of $\beta 2$ microglobulin in rheumatoid arthritis. Ann Rheum Dis 1978; 37: 328-332

[30] Sjöblom KG, SAxne T, Wollheim FA. Plasma levels of $\beta 2$-microglobulin in rheumatoid arthritis. Ann Rheum Dis 1980; 39: 333-339

[31] Walters MT, Stevenson FK, Goswami R et al. Comparison of serum and synovil fluid concentrations of $\beta 2$-microglobulin and $C$ reactive protein in relation to clinical disease activity and synovial inflammation in rheumatoid arthritis. Ann Rheum Dis 1989; 48: 905-911

[32] Shi C, Zhu Y, Su Y et al. Beta-2 microglobulin: Emerging as a promising cancer therapeutic target. Drug Discov Today 2009; 14: 25-30

[33] Balint E, Sprague SM. Beta (2)-microglobulin and bone cell metabolism. Nephrol Dial Transplant 2001; 16: 1108-1111

[34] Tsai CY, Wu TH, Yu CL et al. Increased excretions of beta2-microglobulin, IL-6, and IL-8 and decreased excretion of Tamm-Horsfall glycoprotein in urine of patients with active lupus nephritis. Nephron 200: 85 207-214
[35] Olsen N, Sokka T, Seehorn CL et al. A gene expression signature for recent onset rheumatoid arthritis in peripheral blood mononuclear cells. Ann. Rheum. Dis. 2004; 63: 1387-1392

[36] Mavragani CP, La DT, Stohl W et al. Association of the response to tumor necrosis factor antagonists with plasma type I interferon activity and interferon-beta/alpha ratios in rheumatoid arthritis patients: a post hoc analysis of a predominantly Hispanic cohort. Arthritis Rheum 2010; 62: 392-401

[37] Wendling D, Mas J, Chatelain F et al. Serum beta 2-microglobulin and ankylosing spondylitis. Rev Rhum Mal OSteoartic 1989; 56: 441-443

[38] Kepekçi Y, Boğa C, Başlamışı F et al. Ankilozan Spondilitli olgularda serum beta-2 microglobulin düzeyleri ve hastalık aktivitesi ilişkisi. Gaziantep Üniversitesi Tıp Fakültesi Dergisi 1992; 3: 155-161

[39] Beersma MF, Derhaag PJ, Feltkamp TE. Serum levels of beta 2-miroglobulin in HLA-B27 + patients with acute anterior uveitis and ankylosing spondylitis. Scand J Rheumatol Suppl 1990; 87: 104-107 